\title{
SMART CITIES AND ROBOTIC TECHNOLOGIES FOR A MODEL OF INTEGRATED GROWTH
}

\author{
CIUDADES INTELIGENTES Y TECNOLOGÍAS \\ ROBÓTICAS PARA UN MODELO DE CRECIMIENTO \\ INTEGRADO
}

\author{
Elena Laudante \\ (University of Campania Luigi Vanvitelli) \\ elena.laudante@unicampania.it
}

Recibido: 4 de febrero 2021 / Aceptado: 2 de marzo 2021

Resumen: El articulo se centra en la importancia de la robótica y la inteligencia artificial dentro de los nuevos contextos urbanos en los que es posible considerar y mejorar las diferentes dimensiones de la calidad de vida como la seguridad y la salud, la calidad medioambiental, la conexión social y la participación ciudadana. Las tecnologías inteligentes ayudan a las ciudades a afrontar los nuevos retos de la sociedad, haciéndolas más habitables, atractivas y receptivas para planificar y mejorar la ciudad del futuro. De acuerdo con el Programa de la Agenda 2030 para el desarrollo sostenible que persigue la ciudad inclusiva, segura, resiliente y sostenible, se sigue la dirección de crecimiento y prosperidad de los entornos urbanos optimizando el uso de los recursos y respetando el medio ambiente.

La ciudad actual va más allá de la definición de ciudad inteligente. De hecho, como dijo Carlo Ratti, se convierte en una «ciudad sensible», una ciudad capaz de sentir pero también sensible y capaz de responder a los ciudadanos que definen el rendimiento global de la ciudad. El enfoque multidisciplinar a través del diálogo entre diseñadores, arquitectos, ingenieros y urbanistas permitirá afrontar los nuevos retos a través de la dinámica de integración de los robots en el paisaje urbano. A través de la identificación de casos de estudio representativos será posible destacar las conexiones entre el diseño, la ciudad inteligente y la robótica «urbana» que pondrán de manifiesto de forma sinérgica las principales cualidades «deseables» de la vida en la ciudad como lugar de experimentación y transformaciones radicales. El articulo intenta destacar la importancia de la disciplina de la robótica en el contexto urbano como valor adicional para las ciudades. A través de la aplicación de tecnologías robóticas será posible rediseñar radicalmente los escenarios de desarrollo urbano, invirtiendo así en procesos de innovación de los espacios materiales e inmateriales de la ciudad actual. 
Palabras clave: Diseño emocional; Movilidad innovadora; Robótica urbana; Experiencia de los usuarios; Sociedad inteligente.

Abstract: The paper focuses on the importance of robotics and artificial intelligence inside of the new urban contexts in which it is possible to consider and enhance the different dimensions of quality of life such as safety and health, environmental quality, social connection and civic participation. Smart technologies help cities to meet the new challenges of society, thus making them more livable, attractive and responsive in order to plan and to improve the city of the future. In accordance with the Agenda 2030 Program for sustainable development that intends the inclusive, safe, resilient and sustainable city, the direction of growth and prosperity of urban environments is pursued by optimizing the use of resources and respecting the environment. The current city goes beyond the definition of smart city. In fact, as said by Carlo Ratti, it becomes a «senseable city», a city capable of feeling but also sensitive and capable of responding to citizens who define the overall performance of the city. The multidisciplinary approach through the dialogue between designers, architects, engineers and urban planners will allow to face the new challenges through the dynamics of robot integration in the urban landscape.

Through the identification of representative case studies, it will be possible to highlight the connections between design, smart city and «urban» robotics that will synergically highlight the main «desirable» qualities of life in the city as a place of experimentation and radical transformations. The paper aims to highlight the importance of the robotics discipline within the urban context as the added value for the cities. Through the application of robotic technologies, it will be possible to radically redesign the scenarios of urban development, thus investing in innovation processes of the material and immaterial spaces in the current city.

Keywords: Emotional design; Innovative Mobility; Urban Robotics; User Experience; Smart Society.

\section{Introduction}

We are experiencing a real technological revolution that will find answers that will generate innovative services and solutions in order to promote the territory. These are avant-garde cities that bring about a change in the interaction between the user and the urban environment through the constant use of current technologies. 
Current cities identify themselves as places of innovation and exchange, but at the same time places of complexity from which to create an egalitarian and open society, creating within the urban fabric the optimal conditions to simplify people's lives and improve their quality.

In the current society, robotic technology is proposed as a tool for innovation and evolution in urban as well as industrial and domestic contexts. On the one hand the userscitizens who participate dynamically in the activities and on the other the new technological systems integrated in the urban fabric.

Existing urban systems that are «amplified» of artificial and digital intelligence and give life to smart cities, physical places that allow new forms of coexistence between humans and robots.

We can find «human centered» innovative solutions and services thus responding to the particular needs of people in an effective and dynamic way in order to implement the level of quality of life.

Contexts in continuous movement, made of different flows and relationships that define a privileged place of experimentation and sustainable and innovative transformation.

As Calvino said in the past, cities are considered a set of many things as memory, desires, signs of a language; places of exchange that are not only exchanges of goods, but also of words, desires, memories (Calvino, 1972).

The concept of Smart City, much broader than the exclusively technological one, has entered the common language and deepens the potential and scenarios through different lines of research in order to create processes for the improving of the environmental performance of the city and increasing the efficiency of energy services, mobility, assistance.

Industry 4.0 technologies are undoubtedly the main tool to implement the city through digitization and urban automation, identifying strategic areas such as transport, robotics, health, resource optimization, employment, public safety.

The main world cities are working on artificial intelligence in order to increase the level of smartness and ensure a comfortable life, which induces positive changes in citizens' behavior and in their «way of using» the city. 


\section{Smart City and Europe 2030 program}

The concept of smart city stems from the need to operate in a coordinated manner for the development of a territory through the active involvement of citizens and broadening prospects and horizons. A smart city is an urban space capable of facing challenges related to sustainable development and as Marciano (2015) asserts:

is a phenomenon of social change in progress, so you must turn the attention both to its ideal world and to the material, both representations and codes with which it is shaped its model in social discourse, both infrastructure and organizational devices that incorporate the model and qualify the Smart City as a unique city in history (p.15).

It innovatively addresses the problems and needs of the citizen, exploiting current technologies to reduce the impact on the environment and for the definition of new models of management and governance of the city. A Smart City actively acts through widespread and shared policies to increase the competitiveness and attractiveness of the territory, with particular attention to social cohesion, the dissemination of knowledge, creative growth, accessibility, usability of the environment and the quality of the landscape and the lives of citizens.

As indicated from Follesa, modernity has brought with it a new system of relations, between people and things and between things and places, largely due to productive changes and the economic and social consequences generated by them (Follesa, 2013, p.33).

The city of the future with fewer resources can produce more services for users, uses intelligent management systems to reduce waste and negative environmental, economic and social impacts.

It is a city that uses the intelligence of new technologies to build a sustainable, welcoming and efficient human environment, generating an inclusive system of relationships that attracts, welcomes and accompanies citizens. «Cities, better still, urban environments, will increasingly be the place of the most decisive challenges facing humankind in the decades to come» (Vianello, 2013, p.13).

In detail, the development of a smart city takes place through the definition of widespread networks in which communities play an active role, energy production and management use innovative systems and facilitates investment in renewable energy, focusing on energy savings at different levels, public and private. The economy is developed mainly through systems of interaction between citizens and businesses, defines a place of identity, 
finding adequate value in a system of services to promote and enhance the specificity, increasing the added value.

A smart city aims to integrate technological development through six main axes: Smart Economy, Smart Mobility, Smart Environment, Smart People, Smart Living and Smart Governance.

As far as Smart Governance is concerned, participatory processes, transparency, bottom-up design, thematic and territorial discussion tables and new technologies for the dialogue between administration and citizen are implemented. For Smart Living, life quality is a fundamental element through actions for improvement of accessibility and cultural growth, systems that define greater personal security, greater quality residential and urban planning, training and cohesion.

The importance of competitiveness through the support for innovation and start-up, the improvement of entrepreneurial attractiveness, increasing local productivity, opening up to internationalization and labor market flexibility are the main factors for Smart Economy.

When we talk about of Smart People, the importance of social capital is defined by increasing the level of qualification, plurality and social integration, greater investment in creativity, consolidation and support of widespread networks and the removal of physical and cultural barriers.

In addition, for the Smart Environment, the Smart City mainly takes into account environmental factors through the enhancement of natural resources and the landscape, the reduction of pollution, the increase of environmental protection and sustainable management of resources.

Finally, Smart Mobility underlines the importance of transport and ICT in order to increase local accessibility, improve external and international accessibility, sustainable mobility and at the same time increase security, the use of innovative and environmentally friendly transport and ICT and broadband networks [Fig. 1].

So, a Smart City is a human scale, shared and connected city, in detail is an organic city, a system of systems, which in urban space faces the challenge of globalization considering competitiveness, attractiveness, inclusiveness (Bonomi \& Masiero, 2014). 


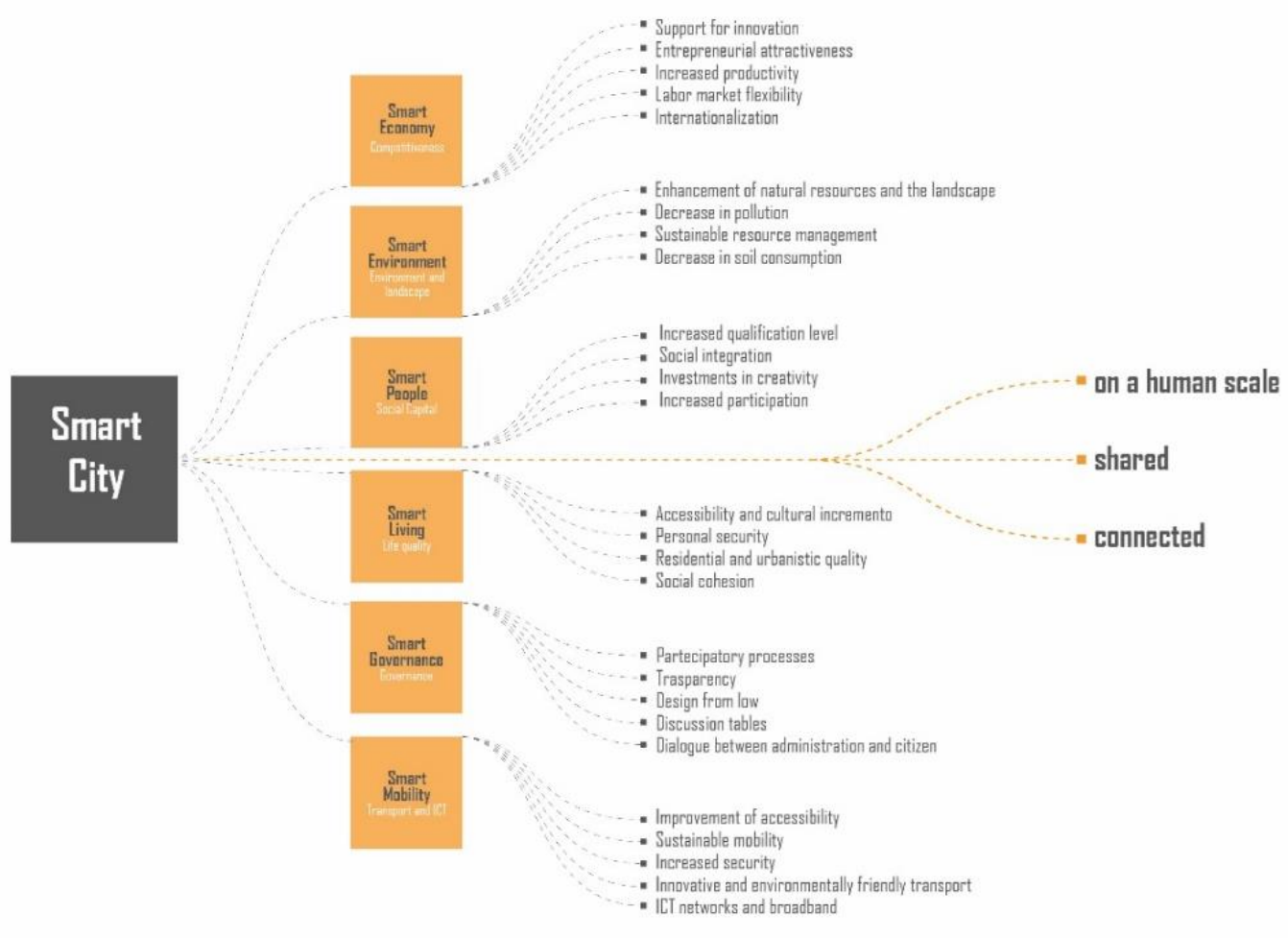

Fig. 1: Schematization of Smart City. (CAuthor, 2019)

Outlining a future in terms of smartness and sustainability, it is necessary to recall the Agenda 2030 Program for Sustainable Development, which represents the result of an innovative path and the paradigm shift that places in a balanced and integrated way the three different dimensions of sustainable development: economic, social and environmental.

Signed in September 2015 by the governments of the 193 UN member countries, the Program of Action determines the commitments on sustainable development to be implemented and achieved by 2030 through the identification of 17 global objectives (Sustainable Development Goals, SDGs) that include 169 specific targets, grouped into 5 priority areas (People, Planet, Prosperity, Peace, Partnership).

The universal objectives are aimed at developing countries as well as advanced countries and cover the various areas essential to ensuring the well-being of humanity and planet, such as the fight against hunger, the elimination of inequalities, the protection of natural resources, urban development, etc.

Specifically, Objective 11 of the Program highlights the importance of the smart and sustainable city as a place where social and economic conditions can be improved in order to meet current growth challenges, improving resource use and offering opportunities for all and making cities and human settlements as inclusive, safe, durable and sustainable. 
This objective aims to ensure access for all to adequate, safe and affordable housing and basic services and to a safe and accessible transport system by 2030, to enhance inclusive and sustainable urbanization and the capacity to plan and manage participatory human settlement, to safeguard the world's cultural and natural heritage, reducing the negative environmental impact of cities and paying particular attention to air quality and urban waste management.

\section{Robotic and Smart City}

Smart mobility and digital innovation are the main themes for the changing city of the future process through a participatory, integrated and sustainable approach. The use of robotic technology is the enabling factor for the development of new forms of innovation in the territory as the keystone for urban futures and new models of innovative society.

Robotics is identified as the discipline that develops machines capable of replacing man in the execution of tasks, in terms of physical activity and decision-making. It is a branch of engineering, and precisely of mechatronics, in which the approaches of humanistic disciplines such as linguistics and science such as biology, physiology, psychology, automation, electronics, physics, computer science, mathematics and mechanics converge.

Highly interdisciplinary in nature, robotics investigates the behavior of «intelligent beings» and develops methodologies to allow the robot to perceive the surrounding environment and interact with it to perform specific tasks that are tiring, repetitive, precise, fast or dangerous for humans.

Robotics was born in the industrial field and represents one of the enabling technologies of Industry 4.0 mostly used in the current production chains. Within the assembly line, in fact, the use of robots has found applications for reducing costs and improving processes. Among the most used robots in the industry, we can find the robotic arm or manipulator robot, built in imitation of the human arm which represents a versatile machine in the different phases of the process including painting, welding or assembly.

Due to its interdisciplinary approach, the discipline of robotics has numerous applications in different contexts. In the field of military robotics, robots are used for reconnaissance and surveillance purposes, as unmanned aircraft or drones, remotely controlled and can perform tasks in total autonomy. Space robots are represented by exploratory probes used in missions on the planets of the solar system. In the biomedical 
field, robotics is used to assist the doctor during surgical operations and through telepresence technologies that allow remote operation.

The implementation of robotics and artificial intelligence within the urban context represents the new paradigm for the enhancement and knowledge of the city and for improving performance in different indicators of quality of life, making the best possible use of technology and thus develop solutions, improving the ecosystem and environmental impacts. The synergy between robotic technology and the urban context will lead to the generation of new models of innovative society in which citizens will share their everyday life with the new robotic actors [Fig. 2].

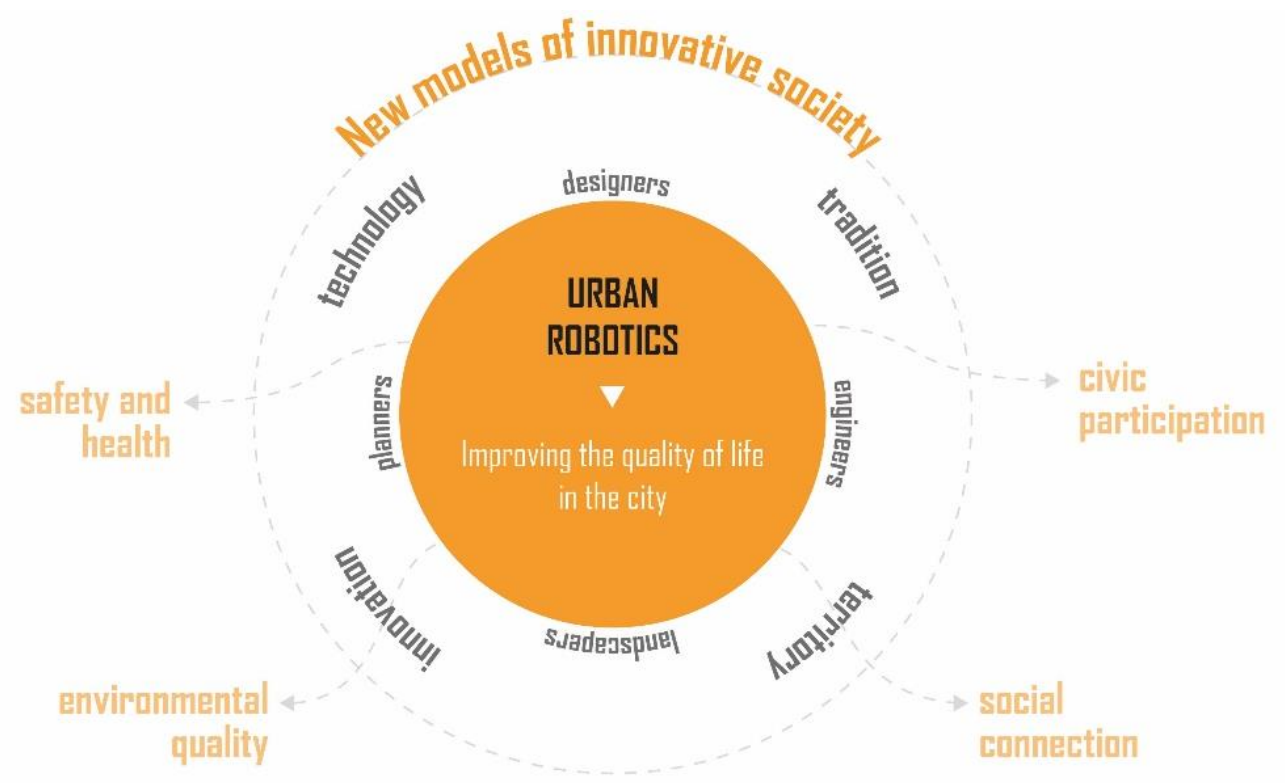

Fig. 2: Identification of new models of innovative society (CAuthor, 2019)

\begin{abstract}
We therefore need a new culture of city design that combines the approaches of simplification, support and - where applicable - automation of urban processes proposed by the major ICT players, with tools for the protection, management and enhancement of cultural heritage $[. .$.$] that ensures not only that intelligence moves from technology to the$ city, to its processes, to its infrastructure - but that it also takes care (without excessive and artificial spectaclizations) of the heart of the city (Granelli, 2012, p.7).
\end{abstract}

With the advancement of technology and the evolution of contemporary industrial, social and cultural society, the city is changing and recording a transformation generated by experiments on artificial intelligence, robots, flying machines and driverless machines that represent the future of intelligent mobility. 


\section{Robots in the city: study cases}

The cities of the future will be pervaded by autonomous driving vehicles, robotized delivery systems and light transport solutions, in response to the new concept of smart mobility, on a human scale, shared and connected mobility.

Through a survey of the types of robotic systems that it will be possible in the next future to find within urban contexts, some representative case studies have been identified that best exploit the potential of technology for improving the quality of life of citizens: autonomous vehicles, innovative delivery systems, light transport systems, monitoring systems for the city, construction systems. Projects of innovative solutions able to increase sustainable mobility in the city, raising greater awareness of the urban ecosystem to the citizens have been described to relate the factors of robotic technology with the approaches of the design discipline.

\section{HANG 184 - Autonomous vehicle}

The Ehang 184 drone, presented at CES 2016, designed by the Chinese drone-building company Ehang, is characterized by larger dimensions, similar to those of a helicopter, which allow the real revolution compared to the current drones: the transport of people.

It is a drone-taxi, a revolutionary quadricopter self-driven for the transport sector, environmentally friendly because it moves thanks to electricity, is fast and does not create problems for the city traffic. The Ehang 184 has an autonomy of twenty-seven minutes and is able to carry a single passenger weighing up to $100 \mathrm{~kg}$ and with a small hand luggage [Fig. 3].

The seat reminds the Formula 1 single-seaters, but the most important innovation is linked to the controls. Once the passenger has boarded the car, he simply has to indicate the destination on an LCD screen, after which the vehicle will take care of everything else independently. The drone will take off, land until the route to follow so as not to risk hindering passenger or cargo aircraft. The destination can also be chosen through the application to be installed on your smartphone. 


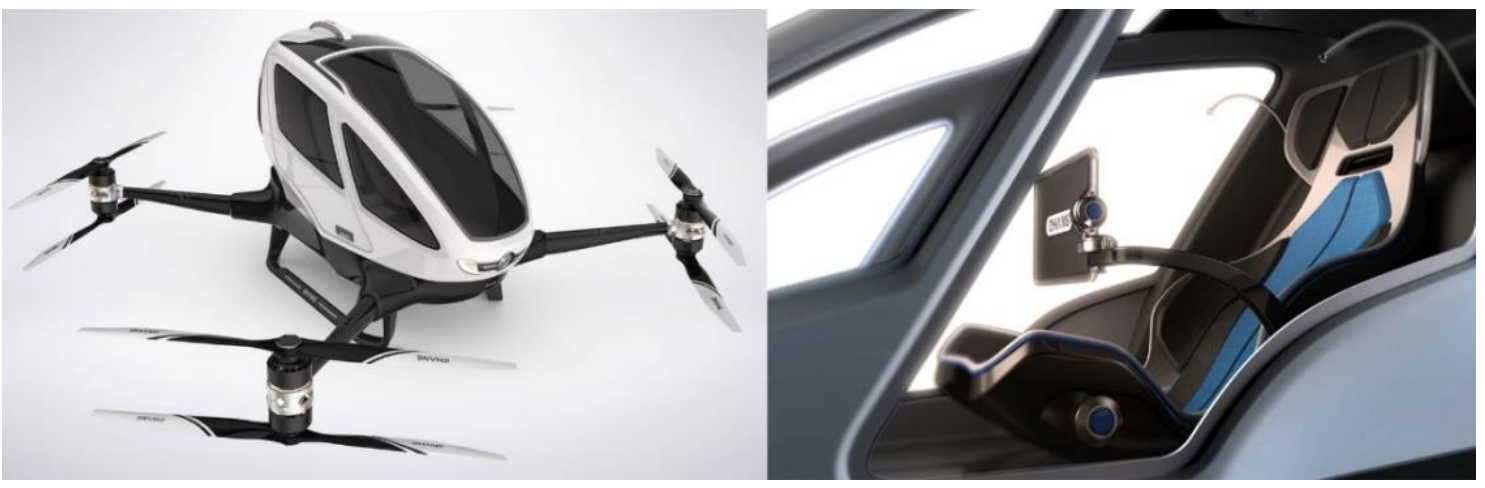

Fig. 3: EHANG 184 System

Passengers are not left to their own devices: An Operations Centre remotely monitors all activities via the $4 \mathrm{G}$ network with the possibility of intervening on the controls in the event of an emergency. The range is just over $50 \mathrm{~km}$ and the maximum operating speed is 160 $\mathrm{km} / \mathrm{h}$, but the usual operating speed will be $100 \mathrm{~km} / \mathrm{h}$.

The Chinese company is not at first experience in the field of drones, in recent years has built several quadricopters for recreational use. However, the Ehang 184 is completely different, since it allows people to be transported from one part of a city to another.

\section{Robomart - Delivery systems}

Robomart represents the new idea of Self driving store for food products that can be sold, prepared or heated at the moment by the self-driving system [Fig. 4]

The project was presented at Ces in Las Vegas 2018 and consists of a fruit and vegetable shop on wheels, with shelves and products. The system was designed in order to improve the lives of consumers and retailers. It works under license, grocery stores can license a Robomart for a 24-month lease, which includes a wireless charger, a vehicle tracking management system and a white label app. Retailers will decide what to store in their Robomart and can customize the vehicle with a store's brand and logo. Consumers will be able to access the service via a smartphone app and order Robomart's «pass». The purchase is made directly on site: once the destination is reached, the robot opens an automatic counter and makes the food accessible. The customer takes what is necessary, which is recorded by cameras. A receipt of the items picked up will then be sent to the customer. The technology used by the «travelling shop» is based on Nvidia 5 Autonomy Driving Platform. The vehicle can make local deliveries at a speed of about $40 \mathrm{~km}$ per hour covering about $110 \mathrm{~km}$ at full load. 

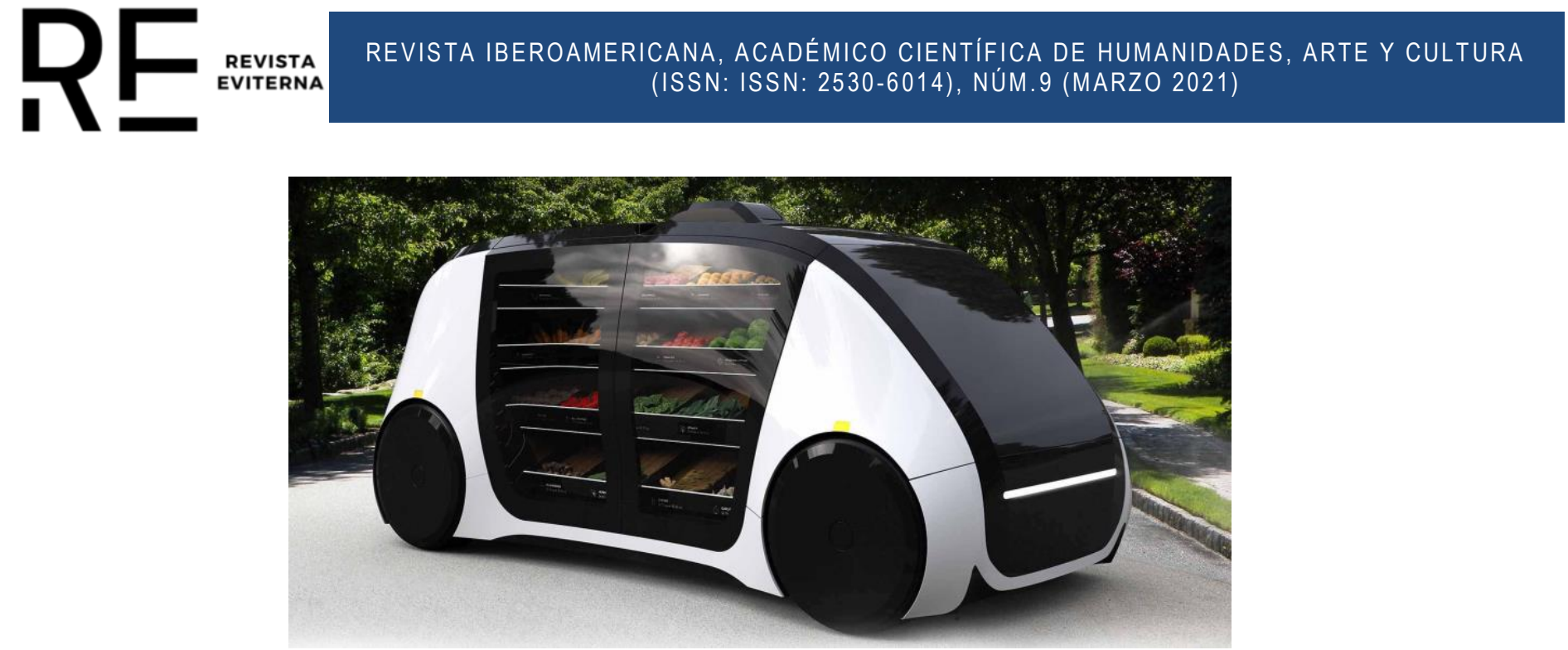

Fig. 4: Robomart System

\section{Gita - Light transport systems}

The American research center Piaggio Fast Forward presents «Gita», the robot that follows human beings and is committed to «facilitate a pedestrian lifestyle».

Gita is an intelligent vehicle capable of moving independently and improving urban mobility, maps the environment surrounding a person, stores and exchanges data through a series of sensors, facilitates the user in the transport of luggage or other objects [Fig. 5]

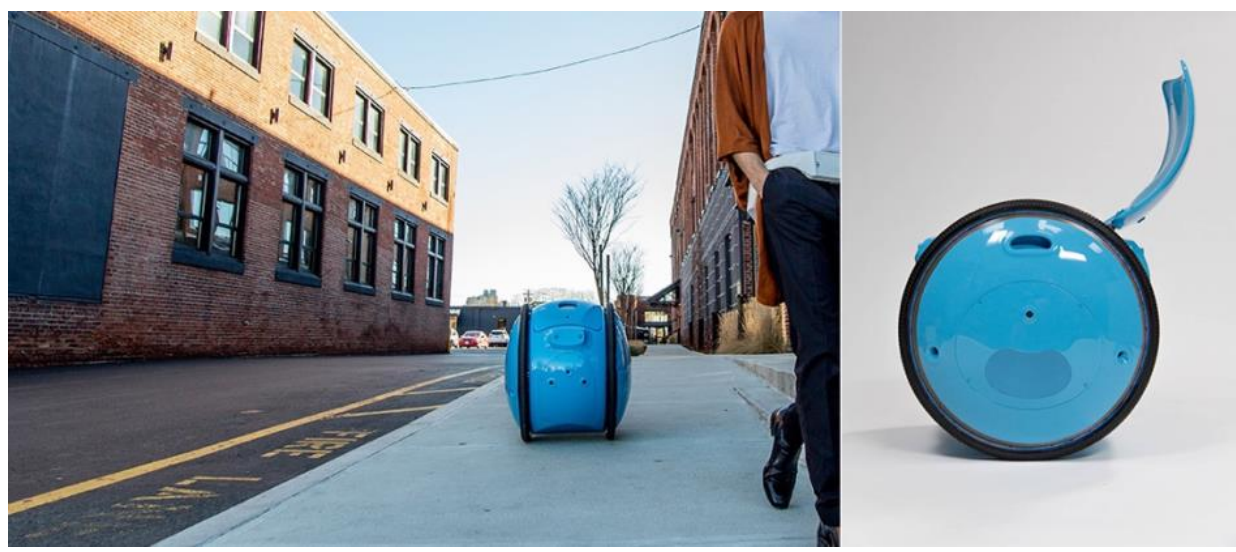

Fig. 5: Gita System

The innovation lies in the support that it will be able to give people in the different activities that distinguish the movements in everyday life in the city, a platform for mobility that can be customized and integrated to meet different needs in different scenarios.

In addition to the comfort, this special robot suitcase can become an important support for those who have to live with reduced mobility, such as the elderly, children and people with disabilities. Gita has been designed to connect with other Gita, up to a total of ten units. It is not impossible to think of a courier who arrives near the city center with his 
van, loads the parcels to be delivered into the Trips, and then moves to the pedestrian area with the interconnected drones that accompany him to make the deliveries.

The system has a compartment capable of carrying a weight of up to 22 kilograms and through a complex optical system can move in complete autonomy and follow one or more users connected to it.

Equipped with micro cameras, it is able to identify the movements of the legs, to follow the tracks of the owner, to memorize some paths, so you can cover them even without a person to follow.

\section{Vienna Summer Scout - Monitoring systems}

The «Vienna Summer Scout» monitoring system was designed by designers Johanna Pichlbauer and Mia Meusburger as part of a summer course at the University of Applied Arts in Vienna and developed in order to identify the arrival of summer in the city.

Through the use of high-tech color sensors around the city it is possible to detect the key signs of the summer such as the presence of tree pollen, barbecue smoke, sun protection in the pool water, or the movement of mosquitoes, etc.

In the city of the future, it will be possible to perceive the imperceptible through the strategic positioning of 7 sensors to observe the urban environment and send the data collected to a power plant. Once the maximum thresholds of these «indicators» have been exceeded, it is possible to «confirm» the arrival of summer to the citizens.

The project stems from the idea of considering the emotional potential of cities in order to develop a proposal for a Smart City of the future.

It is a way to live the city as it evolves and becomes intelligent, a Smart City that optimizes routes, manages and monitors resources, making the lives of citizens more comfortable and emotional.

\section{ECO PODS - Construction systems}

The project by Höweler + Yoon called «Eco Pods» stems from the need to transform an abandoned space into a useful and sustainable design solution.

Höweler + Yoon Architecture is a multidisciplinary studio specializing in the integration of architecture, new technologies and public space. 
It is a prefab that becomes a factory for the production of biofuels from algae with a structure that adapts, changes and grows over time. Eco Pods is a temporary vertical bio-reactor of algae for the production of alternative energy and to embellish the city.

This futuristic project involves the use of robots that connected to the building are able to optimize the conditions of algae growth. In fact, to facilitate the growth of algae, the prefabricated capsules to be assembled in series are mounted on mechanical arms that move according to the light in order to optimize the performance of the system, powered by the same energy produced by biofuels.

The flexible and reconfigurable modular units allow the structure to be transformed to meet the different programmatic and economic needs, generating architecture capable of generating an innovative local micro-urbanism, agile and positive.

The Eco Pods project would allow two problems to be solved at the same time: the elimination of urban degradation resulting from the presence of uninhabited buildings and the reduction of environmental pollution.

Eco-Pods is also a research incubator where scientists can test algae species and fuel extraction methods, including new techniques for using low-energy LED lighting to regulate algae growth cycles.

\section{Design, robotics and Smart City for generating innovative company models}

he identification and description of the case studies were used to analyze the action of Design discipline that - in parallel with the new robotic solutions and human-robot interactions will be responsible for designing the total experience of the user who lives in synergy with the robots, thus changing the socio-economic dynamics of the city.

The synergy between the different disciplines allows to undertake an innovative and open path to the development of environments that facilitate and improve the lives of citizens. In the field of Smart Cities, in fact, the importance of introducing design discipline approaches would produce a greater capacity for transformation of the city [Fig. 6].

Ratti says that it is also a very simple equation because it brings together traditional disciplines focused on space - architecture, planning, design - with computer engineering, electronics, etc. and the other disciplines related to human-machine interaction (Ratti, 2013, p.25). 


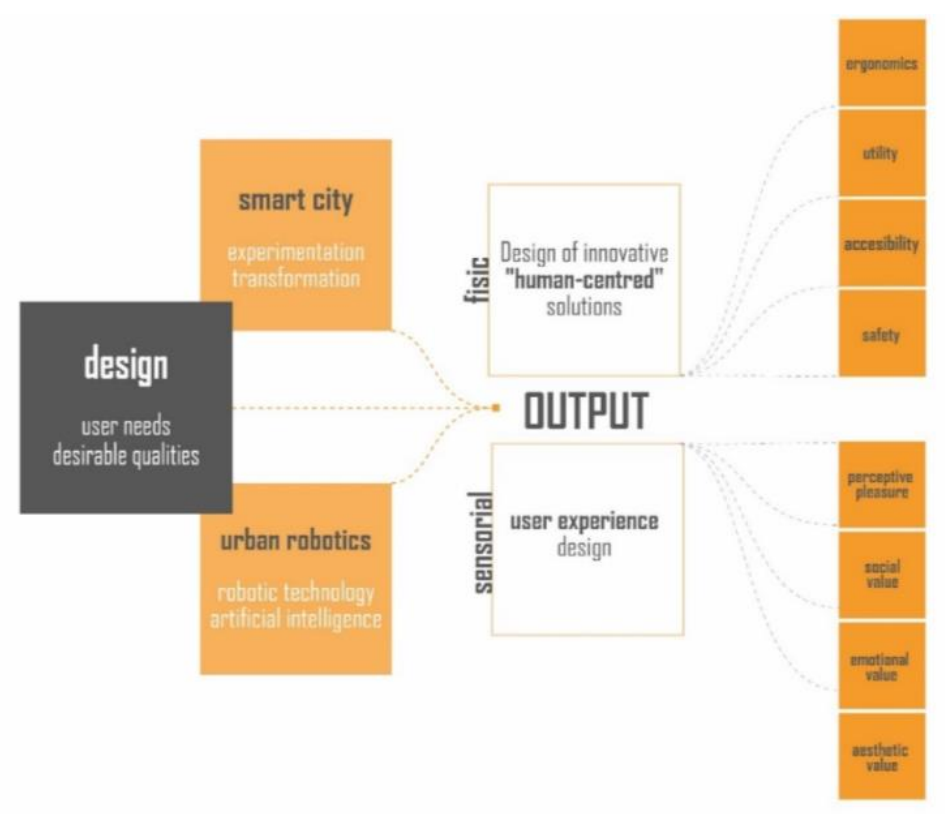

Fig. 6: Project output of robotic solutions for Smart City (CAuthor, 2019)

The interdisciplinary study underlying the analysis and design of a territory represents the desirable way of intervention in which disciplines such as design and robotics find the common ground for the meeting of different knowledge. In fact, «the only way to progress on the road to innovation is to join forces with people from different disciplines and professional backgrounds to try to solve together the great problems of our time» (Ratti, 2013, p.83).

In synergy with robotics within the urban context, Design identifies the main needs and desirable qualities of citizens through experimentation and identification of innovative solutions. In this regard, the architect Carlo Ratti defines the modern city not only as «smart» but also as «sensible city», a city that is able to feel, but also sensitive and able to respond to the citizen in order to improve the overall performance of the city and that «emphasizes the centrality of man within them» (Ratti, 2017, p.27).

Design and architecture play a fundamental role for the definition of spaces and solutions that give rise to the transformation of the city in which the relationship between man and environment will be marked by sustainability and technology.

In this context, the importance of the role for designer is highlighted in order to identify the fundamental references for the correct design process.

Design will have the task of defining and verifying, through the proposed «humancentered» solutions, the physical factors, starting from the factors of ergonomic nature, 
utility, accessibility and safety in the human- new urban robotic systems interaction. The role of the designer will be able to implement physical factors with the perceptual-sensory sphere.

In particular, the perceptive pleasure of man during the use of robotic systems as well as the social and emotional value that results from it will be considered of fundamental importance. Usability and interaction issues represent the starting point for the definition of user-centered design through the analysis of tangible and intangible systems that convey experiences. So, an important element to consider is the aspect defined as «experiential», framed within Experience Design. This approach intends to focus attention on the design and quality of the process and experience during the interaction.

In fact, as reported by Norman, the emotionality represents a crucial element in making decisions. He says that the emotionality, the beauty of a product and the pleasure we derive from it are therefore just as important as the fact that the product functions correctly (Norman, 2014).

\section{Conclusions}

Through the application of «urban» robotics it is possible to generate new models of innovative societies in order to improve the quality of life in the cities. On the one hand the tradition of the territory, on the other hand the of robotic technologic innovation in order to define safety and health, civic participation, environmental quality and social connection.

The intelligent city will become the place where knowledge and culture will take on central significance in development policies, through the creation of integrated networks and the synergy of cultural, social, productive and non-productive components of the territory. The city as a place where the processes of enhancement of the landscape are developed in order to improve the territorial offer and the usability of the places and where the mobility system becomes simple and easy. A mobility able to promote the accessibility of citizens in the urban context, reducing social exclusion through the promotion of active policies, inclusive and attentive to the different needs represented without unequal access to the use of the city.

In this regard, it will be essential to think of a new configuration of the territory, projecting innovative and technological solutions within the city that are able to meet needs and functions, made with scientific and design quality through dialogue between designers, 
architects, landscape architects, and engineers to provide stimuli capable of broadening the horizon of knowledge and creativity of the cities of the future.

A city in which the citizen has an active role, in which «[...] he is not an abstract subject [...], but he presents himself in the scene with his needs, necessities and even with his right to well-being» (Bonomi \& Masiero, 2014, p.111).

In the years to come, robotics and automation will find fertile ground for the transformation of the cities and for the generation of new innovative scenarios.

The cities of the future will be oriented towards the sharing of the urban context and the human-robot coexistence, creating an ecosystem that can offer the quality of life to citizens.

\section{Bibliography}

Bonomi, Aldo \& Masiero, Roberto (2014). Dalla smart city alla smart land, Marsilio Editori: Milano. [Loosely translated by the author].

Calvino, Italo (1972). Le città invisibili. Einaudi: Torino. [Loosely translated by the author].

Follesa, Stefano (2013). Design e identità. Progettare per i luoghi. Franco Angeli Editore. [Loosely translated by the author].

Granelli, Andrea (2012). Città Intelligenti? Per una via italiana alle Smart Cities, Luca Sossella Editore. [Loosely translated by the author].

Marciano, Claudio (2015). Smart City: Lo spazio sociale della convergenza, Edizioni Nuova Cultura: Roma. [Loosely translated by the author].

Norman, Donald A. (2014). Design della complessità, a cura di Maria Grazia Mattei, Egea Editore: Milano. [Loosely translated by the author].

Ratti, Carlo (2013). Smart city, smart citizen, a cura di Maria Grazia Mattei. Egea Editore: Milano. [Loosely translated by the author].

Ratti, Carlo (2017). La città di domani. Come le reti stanno cambiando il futuro urbano. Giulio Einaudi Editore Torino. [Loosely translated by the author].

Vianello, Michele (2013). Smart Cities. Gestire la complessità urbana nell'era di Internet, Maggioli Editore: Santarcangelo di Romagna (RN). [Loosely translated by the author]. 